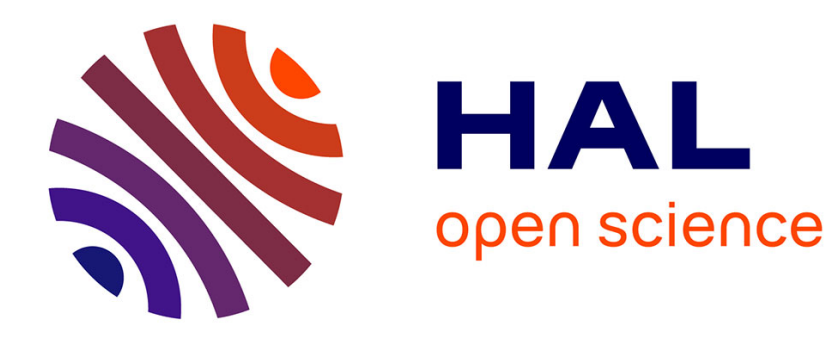

\title{
Toward Organogenesis of Artificial Creatures
}

Jean Disset, Sylvain Cussat-Blanc, Yves Duthen

\section{To cite this version:}

Jean Disset, Sylvain Cussat-Blanc, Yves Duthen. Toward Organogenesis of Artificial Creatures. Genetic and Evolutionary Computation COnference - GECCO 2014, Jul 2014, Vancouver, Canada. pp. 101-102. hal-01136074

\section{HAL Id: hal-01136074 https://hal.science/hal-01136074}

Submitted on 26 Mar 2015

HAL is a multi-disciplinary open access archive for the deposit and dissemination of scientific research documents, whether they are published or not. The documents may come from teaching and research institutions in France or abroad, or from public or private research centers.
L'archive ouverte pluridisciplinaire HAL, est destinée au dépôt et à la diffusion de documents scientifiques de niveau recherche, publiés ou non, émanant des établissements d'enseignement et de recherche français ou étrangers, des laboratoires publics ou privés. 


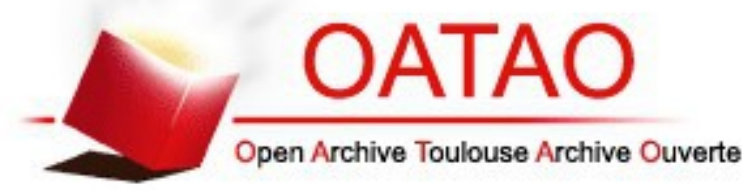

\section{Open Archive TOULOUSE Archive Ouverte (OATAO)}

OATAO is an open access repository that collects the work of Toulouse researchers and makes it freely available over the web where possible.

This is an author-deposited version published in : http://oatao.univ-toulouse.fr/ Eprints ID : 13056

To link to this article : DOI :10.1145/2598394.2598441

URL : http://dx.doi.org/10.1145/2598394.2598441

To cite this version : Disset, Jean and Cussat-Blanc, Sylvain and Duthen, Yves Toward Organogenesis of Artificial Creatures. (2014) In: Genetic and Evolutionary Computation COnference - GECCO 2014, 12 July 2014 - 16 July 2014 (Vancouver, Canada).

Any correspondance concerning this service should be sent to the repository administrator: staff-oatao@,listes-diff.inp-toulouse.fr 


\section{Toward Organogenesis of Artificial Creatures}

\author{
Jean Disset \\ University of Toulouse \\ IRIT - CNRS UMR 5505 \\ 2 rue du Doyen Gabriel Marty, \\ 31042 Toulouse, France \\ jean.disset@irit.fr
}

\author{
Sylvain Cussat-Blanc \\ University of Toulouse \\ IRIT - CNRS UMR 5505 \\ 2 rue du Doyen Gabriel Marty, \\ 31042 Toulouse, France \\ cussat@irit.fr
}

\author{
Yves Duthen \\ University of Toulouse \\ IRIT - CNRS UMR 5505 \\ 2 rue du Doyen Gabriel Marty, \\ 31042 Toulouse, France \\ yves.duthen@irit.fr
}

\begin{abstract}
This paper presents a new model for the development of artificial creatures from a single cell. The model aims at providing a more biologically plausible abstraction of the morphogenesis and the specialization process, which the organogenesis follows. It is built upon three main elements: a cellular physics simulation, a simplified cell cycle using an evolved artificial gene regulatory network and a cell specialization mechanism quantifying the ability to perform different functions. As a proof-of-concept, we present a small experiment where the morphology of a multicellular organism is guided by cell weaknesses and efficiency at performing different functions under environmental stress.
\end{abstract}

General Terms: Algorithms, Experimentation

Keywords: Organogenesis, Gene regulatory networks

\section{INTRODUCTION}

In nature, the cellular specialization (or differentiation) process allowing a single celled organism to grow organs of various shapes and functions is a key mechanism in the development of complex morphologies, behaviors and developmental strategies. This work offers to investigate the emergence of morphologies, developmental capabilities and behaviors of a multicellular simulation implementing a simple specialization system. Contrary to many other models $[4,3$, $1,5,6]$, this system does not rely on any global controller nor has to enforce any particular differentiation pattern or morphology through a fitness function, but has to find developmental strategies to adapt to a hostile environment as well as a more biologically plausible specialization process.

\section{MODEL}

The model is designed with the intent of being relatively close to biological reality in terms of actions and capabilities offered to the cells. In particular, we focused on three main components:

Artificial chemistry. We can subdivide the artificial chemistry layer in two parts: morphogens and energy management. First, the diffusion of morphogens in the environment is used by the cells in order to communicate and gain, for example, positional informations. Morphogens are characterized by their attenuation speed and their evaporation rate. They are diffused through a grid and their concentrations are interpolated across the nearest grid cells in order to smoothen the morphogen gradient. Secondly, cells need to manage their energy levels (every cellular actions costs various amounts of energy). Two forms of energy are introduced: pure energy, which is the actual energy the cell can use to perform various actions and ambrosia, which is an energy storing molecule produced via nutrients present in the environment. Ambrosia can be shared, stored in large quantities and transformed into pure energy and is thus to be compared to sugar molecules in living cells.

Cell physics. We use a mass-spring-damper system that allows for the simulation of cellular collisions and adhesions. Cells can freely move or aggregate into clusters according to their stifnesses and adhesion capabilities.

Cell actions and specialization tree. Thanks to an artificial gene regulatory network based on Cussat-Blanc's model[2], cells are able to perform four main actions, designed after the possible actions and transformations a real living cell can undergo. The division performs an exact copy of a cell (after a growth phase). Apoptosis is the programmed "clean" death of a cell. Quiescence is a "sleeping" state where a cell cannot begin another action for a certain number of decision steps and its energy consumption is reduced. The last action, the specialization process, is at the heart of this work. It is here represented by the walk through a hierarchical tree in which every node contains a set of values to be assigned to the cell's properties. Furthermore, a fixed number of "skill points" are distributed for each specialization states. These points quantify the ability to perform actions such as producing ambrosia from nutrients, storing energy or being able to resist harmful particles. The gene regulatory network controling a cell receives various informations as input: pressure, morphogens concentrations, energy levels and a different set of inputs is used for each specialization state the cell might be differentiated into. A standard genetic algorithm is used in order to evolve the aGRN. 


\section{EXPERIMENTS}

As a proof of concept, we conducted a first experiment taking place in a hostile environment where dangerous particles are aimed toward the center, which is where the first cell appears. These particles are a metaphor of any punctual stress that living multicellular organisms need to face while developing. We manually set up a specialization tree with only two states: the nutritive state and the defensive state. Specialization can only occur from the nutritive state (good efficiency at metabolizing food and producing energy : 10 skill points in energy production, 0 in particle resitance) to the defensive state (good resistance to particles: 10 skill points going to particle resistance, 0 to energy production)

\subsection{Results}

The results show a global increase in the creatures' life time (which is the fitness function, expressed in number of frame) over the generations. By observing the best individuals and by looking at the evolution of the selected genome, generations after generations, we can identify three key developmental strategy elements (depicted on figure 1):

Clusters: After a few generations, cells organize themselves in fuzzy clusters where a few nutritive cells are surrounded by protective cells. This strategy seems to be an effective way to use the specialization states: energy providing cells, which are vulnerable, stay protected from the particles by feeding a shell of protective cells.

Constant renewing: Later in the evolution, when the clusters are formed, cells inside the clusters tend to constantly divide and specialize into defensive cells. This constant renewing makes up for the defensive cells dying be-

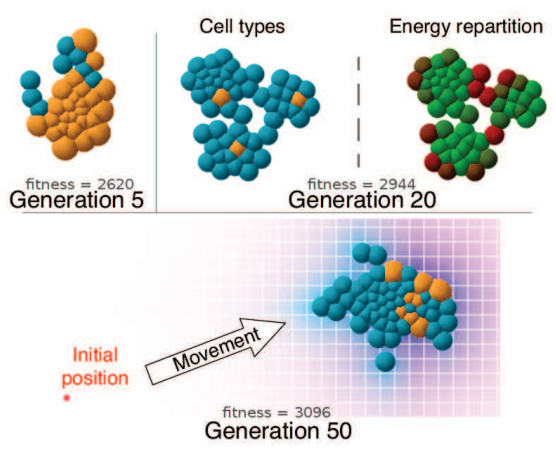

Figure 1: Screen capture of the organisms toward the evolutionary process. After 20 generations, nutritive cells (in orange) aggregate into a cluster and a few defensive cells (in blue) are constantly renewed (their position is not optimal). At generation 20, the organism produces multiple highly organized clusters with a central nutritive cell protected by a field of defensive ones. Energy repartition (showed on the right-hand side, the greener the higher) is remarkably efficient . At generation 40, cells organize themselves into a bigger cluster that asymetrically renews cells in order to escape from the center of the environment, where the particles are concentrated, while keeping a heart of nutritive cells surrounded by a shield of defensive ones. Morphogen gradient appears in the last picture. cause of the aggression of the particles but also because they receive less ambrosia when they are far from the nutritive cells. Cellular clusters tend to be stable in size, and basic reproduction can be observed.

Shifting from the center In this environment, a behavior tends to emerge near the "end" of the evolution runs: movement. Cells tend to avoid the center of the environment which is more dangerous than the outskirts because of the concentric pattern formed by the particles. They use an unbalanced division ratio: division frequency will be higher on one side of the cluster than on the other. We verified that this behavior was not just a consequence of the particles killing cells in the middle of the environment: the same organisms put in a particle free environment demonstrated the same behavior.

\section{CONCLUSION}

This multicellular development model, based on three mains layers, specifically aims to bring a better abstraction of the specialization process in the ontogenetic approach of artificial life. It also aims to avoid the design of an omnipotent multipurpose cell as well as the use of complex fitness functions which would explicitly enforce a desired phenotype. The experiment presented here gave encouraging results as cells specialized into different available types to better fulfill certain function. They adopted a particular morphology and cooperation-based strategy, demonstrating the ability for the model to produce complex developmental plans.

We plan on improving a certain number of aspects of the current model, but the main path we want to investigate concerns the generation of specialization trees. In the experiment presented here, specialization types were manually designed. The next step is to integrate this design directly into the creature's DNA. Optimum cell specialization trees structure as well as skill points distribution will have thus have to be found through an evolutionary process.

\section{REFERENCES}

[1] S. Cussat-Blanc, J. Pascalie, S. Mazac, H. Luga, and Y. Duthen. A synthesis of the cell2organ developmental model. In Morphogenetic Engineering, pages 353-381. Springer, 2012.

[2] S. Cussat-Blanc, S. Sanchez, and Y. Duthen. Controlling cooperative and conflicting continuous actions with a gene regulatory network. In Conference on Computational Intelligence in Games (CIG'12). IEEE, 2012.

[3] R. Doursat. Facilitating evolutionary innovation by developmental modularity and variability. In Proceedings of the 11th Annual conference on Genetic and evolutionary computation, pages 683-690. ACM, 2009.

[4] M. Joachimczak and B. Wróbel. Evo-devo in silico-a model of a gene network regulating multicellular development in $3 \mathrm{~d}$ space with artificial physics. In ALIFE, pages 297-304, 2008.

[5] M. Joachimczak and B. Wrobel. Co-evolution of morphology and control of soft-bodied multicellular animats. 2012.

[6] L. Schramm, Y. Jin, and B. Sendhoff. Emerged coupling of motor control and morphological development in evolution of multi-cellular animats. 5777:27-34, 2011. 